\title{
UPAYA PENINGKATAN RESPONDEN TRACER STUDY DENGAN METODE HIBRID GIS, LBS DAN MEDIA SOSIAL PADA POLITEKNIK HARAPAN BERSAMA
}

\author{
Very Kurnia Bakti ${ }^{1}$, Muhammad Naufal ${ }^{2}$ \\ 1. verykurniabakti@gmail.com, ${ }^{2}$.naufalassalam@gmail.com \\ ${ }^{1 .}$ DIII Teknik Komputer Politeknik Harapan Bersama \\ Jalan Mataram No 9 Tegal
}

\begin{abstract}
Abstrak
Dalam menunjang tercapainya visi dan misi Politeknik Harapan Bersama (PHB), peran dari Tracer Study (TS) sangat dibutuhkan mengingat instrumen $T S$ dapat dijadikan sebagai bahan masukan yang sangat kuatdalam pencapaian kurikulum yang tepat dan sesuai kebutuhan pasar kerja, Sejak tahun 2016 PHB telah menerapkan sistem TS online yang dapat diakses oleh seluruh alumni melalui internet. Beberapa alumni mengeluhkan sistem yang ada tidak dapat menghubungkan antar user. Selain itu, tidak dapat dipungkiri peminat dari aplikasi tracer study terletak pada informasi lowongan pekerjaan. Semakin banyak pengguna aplikasi maka semakin mudah data yang didapatkan dari pengguna aplikasi tersebut. Sistem yang dibuat guna meningkatkan responden pada penelitian ini adalah dengan cara mengubah skema website dari segi tampilan yang user friendly maupun dengan fitur media sosial serta visualisasi informasi lowongan pekerjaan yang akan membantu mempermudah lulusan dalam mencari maupun melakukan sharing pada informasi pekerjaan. Penerapan sistem yang baru ini terbukti berhasil dengan adanya peningkatan jumlah responden yang tahun lalu sebesar 623 dari 903 target lulusan dan tahun ini sebesar 806 dari 1193 target lulusan.
\end{abstract}

Kata kunci: GIS , LBS, Tracer Study, Politeknik Harapan Bersama

\section{Pendahuluan}

Politeknik Harapan Bersama (PHB) didirikan Tahun 2002, yang terletak di provinsi Jawa Tengah. PHB memiliki komitmen untuk mengemban visi dan misi. Visi : menjadi politeknik berstandar nasional dan berwawasan global yang berbasis pendidikan vokasional pada Tahun 2020. Dalam menunjang tercapainya visi dan misi PHB, peran dari tracer study sangat dibutuhkan. Tracer study memiliki beberapa instrumen penting yang berupa kuisioner yang hasilnya diantaranya, dapat dijadikan sebagai bahan pertimbangan masukan yang sangat kuatdalam pencapaian kurikulum yang tepat dan sesuai kebutuhan pasar kerja.

PHB telah mulai menerapkan sistem tracer study pada tahun 2016 melalui situs www.alumniphb.net. Dimana sistem yang dibangun dapat menampilkan form isian kuisioner, berita pekerjaan, agenda dan lain sebagainya Serta sudah dilengkapi dengan sistem SMS Gateway. Namun, dari hasil tracer study yang dilakukan pada tahun 2017 mencapai 70\% dari $80 \%$ target responden. Pada sistem yang dibuat beberapa alumni mengeluhkan sistem yang ada tidak dapat menghubungkan antar user aplikasi. Selain itu, tidak dapat dipungkiri peminat dari aplikasi tracer study terletak pada informasi lowongan pekerjaan. Semakin banyak pengguna aplikasi, maka semakin mudah data yang didapatkan dari pengguna aplikasi tersebut. Konsep media sosial yang dibangun diharapkan akan membantu meningkatkan minat lulusan dalam mengunjungi website agar nantinya memudahkan dalam proses tracer.

Tracer study merupakan susatu kegiatan untuk mendapatkan suatu tanggapan atau umpan balik terhadap apa yang telah didapat selama proses belajar dan bagaimana penerapannya pada saat didunia kerja. Hasil dari tracer study akan membantu suatu perguruan tinggi untuk mengetahui lulusan yang terserap dunia kerja, serta mengetahui kemampuan apa saja yang dibutuhkan di dunia kerja. [1]

Dalam proses penampilan visualisasi berupa titik koordinat peta diperlukan sebuah teknologi LBS dan GIS. LBS merupakan suatu layanan yang mengeksploitasi seluruh informasi yang dapat diperoleh pengguna berdasarkan lokasinya. Saat ini $L B S$ digunakan dalam berbagai konteks seperti kesehatan, pencarian objek, hiburan, pekerjaan dan lain-lain [2]. GIS merupakan teknologi untuk mengelola, menganalisis dan menyebarkaninformasi geografis. GIS (Geographic Information System) adalah sistem yangberbasis komputer yang digunakan untukmenyimpan data dan memanipulasi informasi geografis [3]. 
Tujuan dari penelitian ini adalah sebagai berikut:

1. Memperoleh jumlah responden tracer study alumni yang signifikan

2. Diperoleh hasil kuisiner sebagai bahan pertimbangan pengembangan/perbaikan kurikulum.

3. Melaporkan hasil tracer study ke Belmawa Ristekdikti

4. Memperoleh poin nilai akreditasi yang baik

\section{Metode Penelitian}

Penelitian dilakukan dengan langkah awal untuk memperoleh data berupa data lulusan tahun 2015 yang diperoleh dari BAA Politeknik Harapan Bersama (PHB). Kemudian data yang didapat dianalisis kemudian dirancang sebelum kemudian diimplementasikan.

\section{A. Desain}

Tahap disain dari proses pelaksanaan Tracer Study adalah dengan menggunakan sebuah sistem penyebaran informasi melalui SMS gateway, yang sudah ada dan dikombinasikan dengan konsep tracer study online yang akan dikembangkan.Yaitu gabungan antara media sosial, GIS dan LBS. Disain dari pelaksanaan Tracer Study dapat dilihat seperti pada gambar 1 dibawah ini.

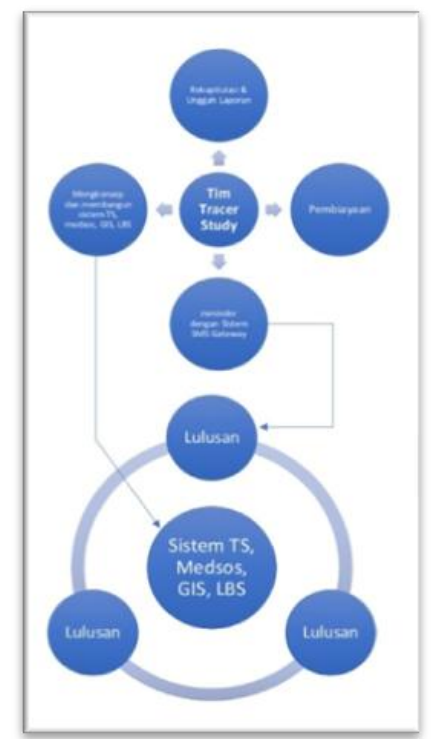

Gambar 1. Desain Pelaksanaan Tracer Study

B. Populasi, Sampel, dan Sumber Data

Berikut merupakan jumlah populasi dari 85\% lulusan 2016 yang dijadikan sebagai bahan penelitian dapat dilihat pada Tabel 1 dibawah ini.
Tabel 1. Jumlah Lulusan Angkatan 2016

\begin{tabular}{|c|c|c|}
\hline No & Program Studi & Jumlah \\
\hline 1 & D3 - Akuntansi & 363 \\
\hline 2 & D3 - Farmasi & 153 \\
\hline 3 & D3 - Kebidanan & 106 \\
\hline 4 & D3 - Teknik Komputer & 421 \\
\hline 5 & D3 - Teknik Elektronika & 90 \\
\hline 6 & D3 - Teknik Mesin & 60 \\
\hline & Total Jumlah Lulusan & 1193 \\
\hline
\end{tabular}

Subyek dari penelitian ditargetkan pada total populasi lulusan PHB tahun 2016 berjumlah 1193 lulusan dan ditargetkan sekurang-kurangnya 85\% lulusan merespon kuisioner tracer study.

C. Metode Pengumpulan Data

Dilakukan dengan metode kualitatif. Dilakukan dengan melakukan wawancara terhadap beberapa alumni dan staf BAA, serta melakukan observasi pada lingkungan kampus PHB.

\section{Metode Pelacakan}

Proses pelacakan yang akan dilaksanakan adalah dengan cara menyebar sms gateway ke nomor ponsel seluruh lulusan tahun 2016 yang data nomor ponsel tersebut didapat dari data buku kenangan wisuda tahun 2016, Nomor ponsel yang didapat kemudian dimasukan kedalam susunan database dalam bentuk excel yang nantinya akan dimasukkan ke dalam sistem sms gateway. Kemudian disusun kalimat text sms yang isinya adalah mengajak para alumni untuk mengunjungi halaman web Tracer Study https://alumniphb.net dengan fitur terbaru dan masuk sebagai alumni untuk mengisi kuisioner Tracer Study. Setelah para lulusan mengakses tracer study yang dikemas dalam bentuk media sosial GIS dan LBS harapannya secara inisiatif para lulusan akan mensosialisasikan kepada para lulusan yang lain, dikarenakan konsep tracer study yang baru memberikan sajian sistem yang tidak membosankan dan merasakan sensasi menggunakan media sosial. Hal inilah yang diharapkan sistem tracer study yang baru akan meningkatkan jumlah responden secara signifikan. Hasil dari respon alumni kemudian diekspor ke dalam bentuk excel dan diunggah di halaman website pkts.belmawa.ristekdikti.go.id untuk dikompilasi sesuai dengan metode yang digunakan pada halaman website tersebut. Untuk lebih jelasnya metode dari proses pelacakan dapat dilihat seperti pada gambar2. 


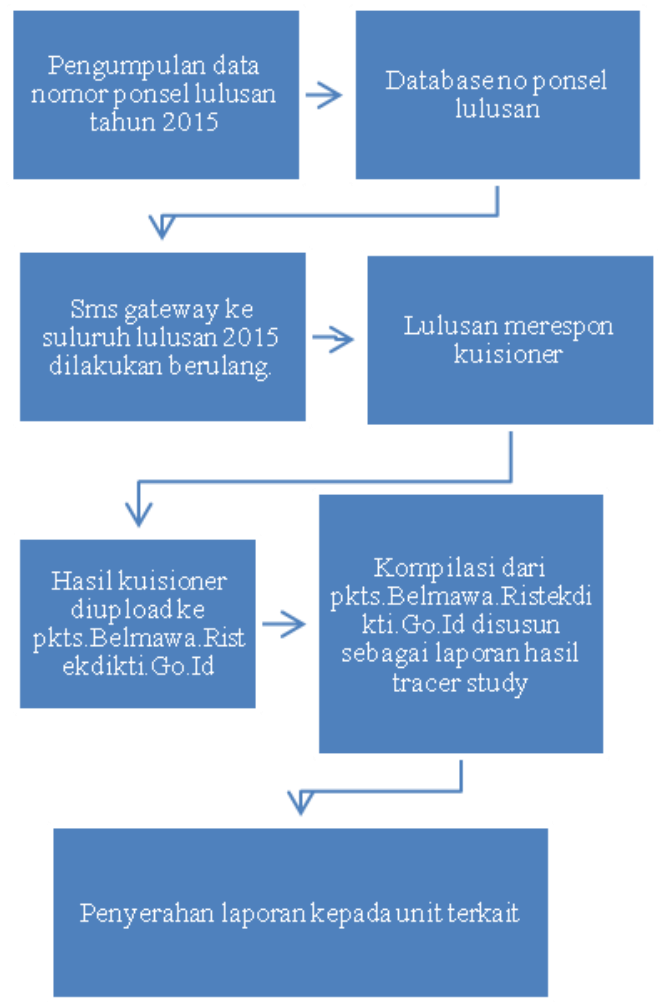

Gambar 2. Proses Pelacakan Tracer Study

\section{Hasil dan Pembahasan}

Hasil dari penelitian ini adalah berupa website TS yang diperbaharui secara keseluruhan baik dari segi tampilanmaupun fiturnya yang condong berkonsepkan media sosial.

\section{A. Tampilan Aplikasi}

1. Halaman Utama Sistem

Merupakan halaman awal ketika url diakses. Didalamnya menampilkan informasi lowongan pekerjaan, berita seputar alumni, agenda dan lain lain dapat dilihat pada Gambar 3.

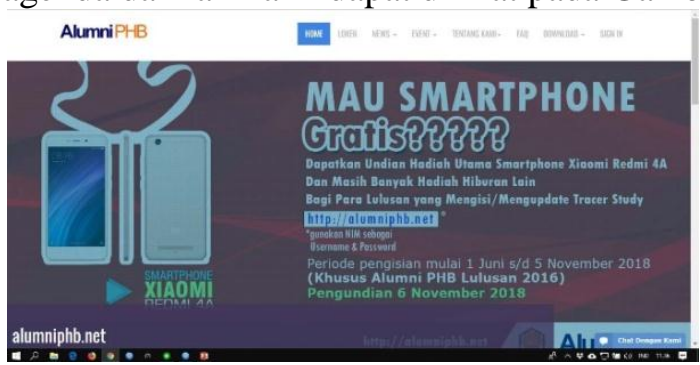

Gambar 3. Halaman Utama Sistem

\section{Beranda alumni}

Disini alumni disuguhi beberapa menu diantaranya adalah lowongan pekerjaa, akun, chating, sebaran alumni dan lain lain. Dapat dilihat pada Gambar 4 dibawah ini.

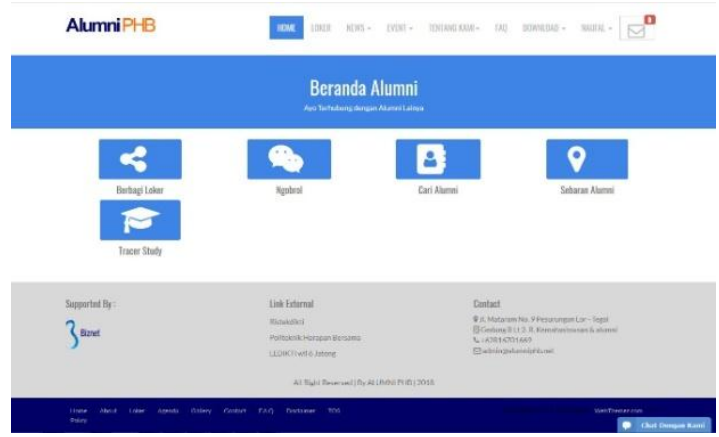

Gambar 4. Beranda Alumni

\section{Menu Admin}

Disini admin dapat mengakses menu admin yang lengkapnya dapat dilihat pada Gambar 5 berikut ini.

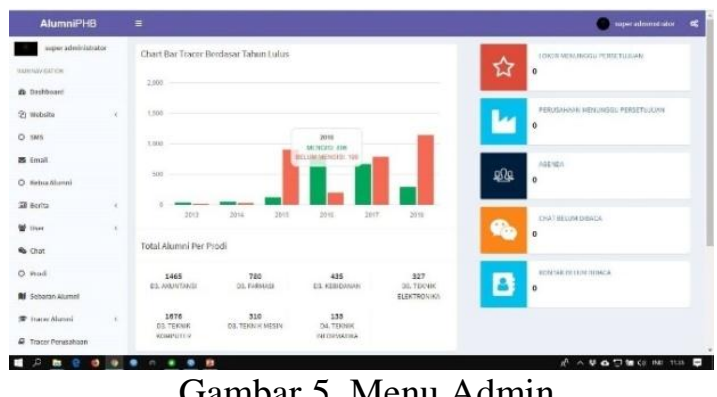

Gambar 5. Menu Admin

\section{Menu GIS Alumni}

Disini admin dapat melihat letak sebaran alumni dengan visualisasi peta dapat dilihat pada Gambar 6 berikut ini.

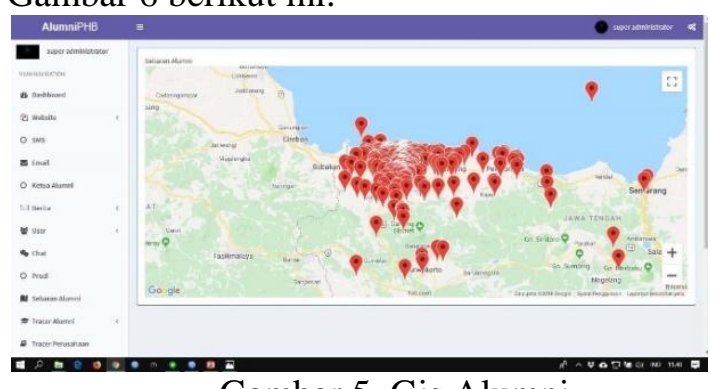

5. Tracking Loker

Disini alumni dapat melihat visualisasi lokasi lowongan pekerjaan dengan rute via alumni terdekat dapat dilihat pada Gambar 6 berikut ini. 


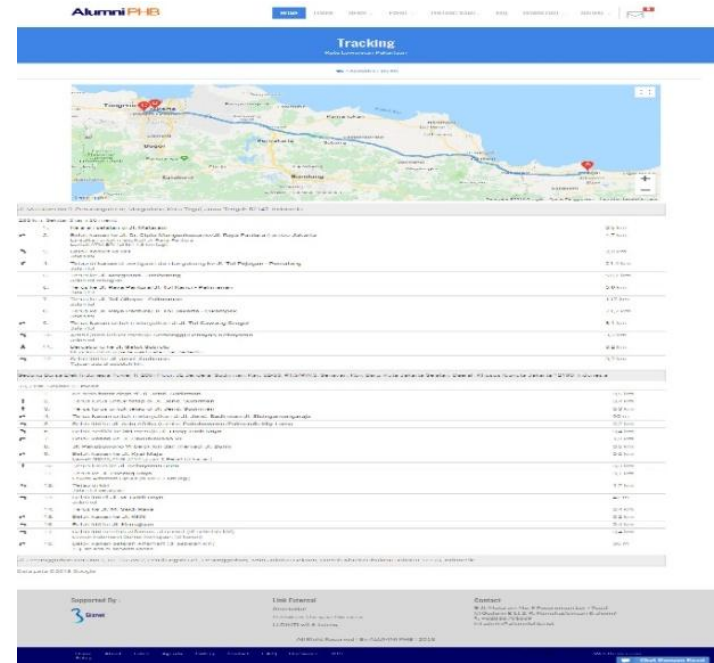

Gambar 6. Tracking Loker

B. Hasil Tracer Study

\section{Responden}

Data persentase responden pengisian pada sistem yang dibangun dapat dilihat pada Tabel 2 berikut.

Tabel 2.Persentase Responden

\section{Masa Transisi}

Masa transisi atau masa tunggu bekerja dari responden dapat dilihat pada Tabel 3 berikut.

\begin{tabular}{|c|c|c|c|c|}
\hline No & Progran Studi & $\begin{array}{c}\text { Jumlah } \\
\text { lulusan }\end{array}$ & Lulusanmerespon & $\begin{array}{c}\text { Presentase } \\
\text { lulusan }\end{array}$ \\
\hline 1. & Kebidanan & 106 & 76 & $71.6 \%$ \\
\hline 2. & Farmasi & 153 & 111 & $72,5 \%$ \\
\hline 3. & Akuntansi & 363 & 224 & $61,7 \%$ \\
\hline 4. & Teknik Komputer & 421 & 289 & $68,6 \%$ \\
\hline 5. & Teknik Mesin & 60 & 41 & $68,3 \%$ \\
\hline 6. & Teknik Elektro & 90 & 65 & $72,2 \%$ \\
\hline & Total & 1193 & 806 & $70 \%$ \\
\hline
\end{tabular}

Tabel 3. Masa Transisi Responden

\begin{tabular}{|l|l|l|}
\hline No & Program Studi & $\begin{array}{l}\text { Waktu Tunggu } \\
(\mathrm{B} 1 n)\end{array}$ \\
\hline 1 & Kebidanan & 1.5 \\
\hline 2 & Farmasi & 2.9 \\
\hline 3 & Akuntansi & 3,4 \\
\hline 4 & Teknik Komputer & 2.4 \\
\hline 5 & Teknik Mesin & 2,4 \\
\hline 6 & Teknik Elektro & 2,6 \\
\hline \multicolumn{2}{|l|}{ Rata-rata } & 2.7 \\
\hline
\end{tabular}

\section{Pekerjaan Sekarang}

Total alumni yang bekerja adalah 790 orang atau $8 \%$, sedangkan alumni yang belum bekerja adalah 2\% dari total alumni yang merespon.Tempat dimana responden bekerja dapat dilihat pada Tabel 4 berikut ini:
Tabel 4. Tempat Responden Bekerja

\begin{tabular}{|l|l|}
\hline Tempat bekerja & Jumlah \\
\hline Pemerintahan & 113 \\
\hline Organisasi Non profit /LSM & 19 \\
\hline Perusahaan Swasta & 415 \\
\hline Wirausaha & 143 \\
\hline Lainnya & 80 \\
\hline
\end{tabular}

\section{Kesimpulan}

Proses persebaran informasi tracer study lebih mudah dan efisien dalam penyampaiannya serta mendapat respon yang cukup baik yaitu $70 \%$ dari 1193 target alumni dan dari 90,97\% dari target 886 alumni.

\section{Daftar Pustaka}

[1] www.pkts.belmawa ristekdikti.go.id.

[2] Fitriyani D, "Aplikasi LBS (Location Based Services) Pada Mobile Phone Dengan Teknologi J2ME (Kasus : Lokasi Fasilitas Umum Di Kota Pekanbaru). Fakultas Sains Dan Teknologi Universitas Islam Negeri Sultan Syarif Kasim Riau," Universitas Islam Negeri Sultan Syarif Kasim Riau,(2011).

[3] Dwidasmara, I. B, "Sistem Informasi Geografis Obyek Wisata Bali Berbasis Aplikasi Mobile Dengan Representasi Data Spasial Menggunakan Xml Svg," Jurnal Ilmiah Ilmu Komputer Universitas Udayana, (2014).

[4] Bakti, V. K, dkk. 2015. "Sistem Informasi Pelacakan Jejak Alumni (Tracer Study) Berbasis Smartphone Pada Politeknik Harapan Bersama". Jurnal Teknologi Informasi dan Komunikasi, ISSN:2087-0868. $6(2)$.

[5] Gabriel, S. 2010. "Beginning Google Maps API 3". USA : Apress

[6] Irwansyah, E. 2013. "Sistem Informasi Geografis : Prinsip Dasar dan Pengembangan Aplikasi”. Yogyakarta : Digibooks.

[7] Maheshwari, Shikha., dan Jain, D. Ch. 2012. "Comparative Analysis Of Different Types Of Models In Software Development Life Cycle". International Journal Of Advanced Research in Computer Science and Software Engineering. 2(5), 285-290.

[8] Wardana. 2012. "Menjadi Master PHP dengan Framework Codeigniter". Jakarta : Elex Media Komputindo. 